IRA-International Journal of Management \& Social Sciences

ISSN 2455-2267; Vol.03, Issue 03 (2016)

Institute of Research Advances

http://research-advances.org/index.php/RAJMSS

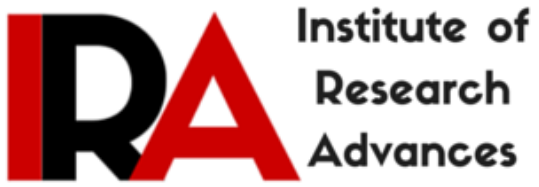

\title{
A Study on Financial Analysis of Indian Leather Exports
}

\author{
${ }^{1}$ Dr. B. Saranya., (M.Com.,M.B.A., M.Phil.,PGDCA.,Ph.D, NET, Head) \\ Department of Commerce, PSG College of Arts and Science, \\ Coimbatore, Tamil Nadu, India. \\ ${ }^{2}$ Dr. V. Kavitha, (M.B.A., M.Phil., Ph.D., Head) \\ Department of Management Studies, PKR Arts College for Women, \\ Gobi, Tamil Nadu., India.
}

DOI: http://dx.doi.org/10.21013/jmss.v3.n3.p5

\section{How to cite this paper:}

Saranya, D., \& Kavitha, D. (2015). A Study on Financial Analysis of Indian Leather Exports. IRA-International Journal of Management \& Social Sciences (ISSN 2455-2267), 3(3). doi:http://dx.doi.org/10.21013/jmss.v3.n3.p5

(C) Institute of Research Advances

\section{(oc) EY-NC}

This works is licensed under a Creative Commons Attribution-Non Commercial 4.0 International License subject to proper citation to the publication source of the work.

Disclaimer: The scholarly papers as reviewed and published by the Institute of Research Advances (IRA) are the views and opinions of their respective authors and are not the views or opinions of the IRA. The IRA disclaims of any harm or loss caused due to the published content to any party. 
ABSTRACT
The history of leather tanning in India dates back to 3000 BC. Tanning in the
rural areas is done by indigenous techniques, making the use of this material easier. The
most popular Indian leather products include footwear and hand bags. The footwear
comes in various designs of traditional embroidery, brocade of textile. Bright colors and
unique designs are used. The all time favorite- Kolhapur chapels of Maharashtra are
very soft and very comfortable to wear. A special type of thickest shoes, called mojadis is
designed in Rajasthan. They are decorated with silk, beads and metal embroidery. Jaipur
is famous for its fancy and sophisticated footwear. Hence, a study on financial analysis
of Indian leather exports are very important in the present day scenario, and hence this
study.

Key words: Indian leather industry, export of leather goods, trend analysis.

\subsection{INTRODUCTION}

"Indian Leather Industry must gear up to be more competitive by adopting economy of scale. The sector has potential for growth and received plenty of inquiries but on account of price competitiveness, many buyers are not able to mature the business contracts with Indian exporters." Discussing the future of the Industry Mr Sethi stated, "Future of Leather Industry in India is bright because of attraction of Europeans and Americans towards India. It has been observed that these traditional markets are gaining confidence in Indian products and its deliveries.

The leather industry occupies a place of prominence in the Indian economy in view of its massive potential for employment, growth and exports. There has been an increasing emphasis on its planned development, aimed at optimum utilisation of available raw materials for maximising the returns, particularly from exports. The exports of leather and leather products gained momentum during the past two decades. Indian leather industry today has attained well merited recognition in international markets besides occupying a prominent place among the top seven foreign exchange earners of the country.

\subsection{OBJECTIVES OF THE STUDY}

- To know the importance of the leather industry in international trade.

- To know about the export performance of leather industry in India.

- To analyze the export performance of leather industry for the year $2010-2015$.

- To estimate the future growth of leather industry in India.

\subsection{SCOPE OF THE STUDY}

- India is the leading producers of leather. The export performance of leather varies from one year to another year.

- This study throws a light on the export performance of leather in India. It also depicts the budgeted future export performance of leather from India. 


\subsection{RESEARCH METHODOLOGY}

\section{Nature of the study}

The data used in the study are secondary data in nature. The data are collected from books, magazines, websites and newspaper.

\section{Period of study}

This study covers the duration of five financial years from 2010 to 2015.

\section{Area of study}

The study covers all over the leather exports from India and data applicable only for India.

\section{Statistical tools}

\section{Growth Percentage Analysis}

A percent growth rate (or sometimes referred to as percent change, growth rate, or rate of change) is a useful indicator to look at how much a population is growing or declining in a particular area. It is also useful when comparing the growth or decline of populations in two different areas or regions. But percent growth rate can be used in other studies besides population (such as employment, unemployment, economic factors, etc.). Any number from one time and any number from another time can be put into the calculation to determine growth rate. This article will show you how to easily calculate the growth rate or percent change.

$$
\text { Growthpercentage }=\frac{\text { curretnntyear }- \text { previousyar }}{\text { previousyar }} * 100
$$

\section{Trend Analysis}

Forecasting technique that relies primarily on historical time series data to predict the future. The analysis involves searching for a right Trend Equation that will suitably describe trend of the data series. The trend may be linear, or it may not. A linear trend can be obtained by using a Least Squares Method. The line has the equation $y=a+b t$ where $t=1,2,3 \ldots, b=$ slope of the line, and $a=$ value of $y$ when $t=0$. The coefficients of the equation, $a$ and $b$, can be determined using these equations:

$$
\begin{array}{lll}
\text { 1) } a=\frac{\sum y}{N} & \text { 2) } b=\frac{\sum x y}{\sum x^{2}} & \text { 3) } y=a+b x
\end{array}
$$

\section{Compound Annual Growth Rate}

The year-over-growth rate of an investment over a specified period of time. The compound annual growth rate is calculated by taking the nth root of the total percentage growth rate, where $\mathrm{n}$ is the number of years in the period being considered.

This can be written as follows:

$$
\text { CAGR }=\left(\frac{\text { Ending Value }}{\text { Beginning Value }}\right)^{\left(\frac{1}{\# \text { of years }}\right)}-1
$$




\subsection{LIMITATIONS OF THE STUDY}

- The analysis made only for five years

- The data conferred are secondary in nature

\subsection{REVIEW OF LITERATURE}

Mammo Muchie (2000) in his article discusses the successful value-added chain within India's leather industry, and then draws contrasts with the evolution of the leather products industries of Kenya and Ethiopia. Much of India's success derives from the ability of its stakeholders-from government to industry- to set their own policies and priorities regarding the development of the leather industry. The fact that India selectively liberalized the entry of a variety of industries into the global economy added to the improved performance of its leather products sub-sector. By contrast, both Ethiopia and Kenya followed different policies regarding liberalization, with differing results. Although the leather industry is important for both countries, moving up the value-added chain remains tenuous at best for Kenya and only slightly better for Ethiopia. This article recommends that both countries need to formulate and implement policies that will move the leather industry from raw and semi-processed production outward to the leather products and leather goods sub-sectors.

Xiaohui Liu (2011) in his article empirically investigates the determinants of Chinese export performance using cross-sectional data at the industry level. We find that the export performance of different industries is significantly influenced by labour costs, foreign direct investment (FDI) and firm size, and thus open to a variety of explanations offered by traditional and new trade theories. These findings indicate that Chinese industrial sectors have realised their comparative advantages, but point to the need for the industries to upgrade their export structure in order to sustain growth.

\subsection{IMPORTANCE OF INDIAN LEATHER INDUSTRY}

- India has enormous potential for future growth

- Leather is 8 export earners for India

- Employment opportunities can each up to 25 million

- Better value additions can be achieved by leather industry

- India's Leather Garments Industry

Leather garments form a significant segment of the Leather Industry in India. Leather garments production capacity is estimated to be 16 million pieces annually. India produces different types of leather garments i.e., jackets, long coats, waist coats/shirts, pant/shorts, motorbike jackets, industrial leather garments, leather aprons etc.

India is the second largest producer of leather garments, next only to China, which produces 70 million pieces of the total global trade volume of about 120 million pieces.

It is a matter of great pride that Indian leather garments have been making giant strides in the world of fashion. National Institute of Fashion Technology and National Institute of Design lends design support to make continuous fashion statements. These Institutes provides well trained personnel and imaginative designers. India's acknowledged strength is leather tanning and its ability to produce a wide variety of fashion leathers. 


\subsection{INDIAN FINISHED LEATHER INDUSTRY}

- Finished Leather Technology to the core

India has amongst the largest livestock population in the world, providing a strong raw material base in goat, buffalo, cow and sheep leather. In terms of raw material availability in pieces, India is endowed with $12.55 \%$ of Bovine hides \& skins, $12.29 \%$ of goat and kid skins, and 3.48\% of Sheep and Lamb skins in the world.

The range of finished leathers include classic finishes (polish, glazed, aniline, patent), matt surfaces (suedes, nubuck), nappa, burnished \& oily leathers, crackled \& distressed finishes etc

Amongst the major producers of finished leather in the world, the Indian Leather Industry has a long tradition of supplying high quality leather for the global market. Indian tanning industry produces over 2 billion square feet of leather per annum. The Industry has the tanning capacity to fulfill $10 \%$ of global leather requirements.

\section{- Life of Indian Leather Industry in a nutshell}

The Indian Leather Industry is serving as a major contributor to the Indian economy, through its export earnings and employment generation potential. In the 1950s and 1960s, the industry was exporting mainly raw hides \& skins and semi-processed leathers. The export of leather and leather products during 1954-55 was USD 48.48 million, with value added leather products constituting only $3.88 \%$. The exports from leather sector increased to USD 66.88 million in 1964-65 and the share of value added leather products increased to $9.39 \%$. However, during the 1970s the Government of India laid emphasis on export of value added leather products and constituted the Seetharamiah Committee which laid the framework for export of value added products from the industry. As a result, the export of value added leather products and footwear began to increase slowly to $20.51 \%$ in $1979-80$.

The 1980s saw the transition phase of the industry from being a supplier of raw materials to an exporter of high quality leather products and footwear. Exports from leather sector reach a value of USD 1218.47 million in 1989-90, with value added leather products constituting a significant share of about 65\%. The 1990s witnessed implementation of long term programmes like the National Leather Development Programme (NLDP) to further consolidate and enhance the growth and development of the Indian leather sector.

\section{- $\quad$ Structure of Leather Industry}

The structure of the industry, as it exists now, presents an interesting spectacle. In tanning and finishing, the country has the capacity for processing 192 million hides and skins per year. A substantial capacity lies in the modern tanneries, the production in cottage and back-yard tanneries registering a steep decline over the years. This is due to the fact that the modern tanneries are able to pay a better price for the raw material in the process, a good quantity of hides and skins, which were earlier not collected, do get collected. These tanneries were set up with a good deal of technological support from foreign buyers and are constantly being modernized, enhancing their capability to produce better quality leathers. The tanning and finishing industry has assumed the characteristics of an organized industry. Footwear, however, presents a different picture. Out of total production of 465 million pairs in 1992, including shoe uppers, except for about 40 million pairs of shoe uppers produced in modern factories, over 80 per cent of foot wear produced in the country came from cottage and small scale units. The production of sports leather shoe is negligible. Those units using non leather materials for footwear have just started coming up and the current capacity is estimated at about 50 million pairs per annum. Leather garments are produced in both, in what may resemble an oversized tailor shop and large modern factories. Leather goods such as handbags and 
gloves are made in small and cottage units and so are saddles and bridles. A significant chunk of the output of the industry still emanates from the small scale and cottage sector.

The distinguishing features of leather industry in India are summarized as under:

- Own raw material source $-21 \%$ of world cattle \& buffalo and $11 \%$ of world goat and sheep population are housed in India

- 2 billion sq feet of leather produced annually

- 2nd largest producer of Footwear and Leather Garments

- 3rd largest producer of saddler and harness items

- Generating employment for 2.5 Million people, mostly from the weaker sections with $30 \%$ women predominance.

- Nearly 60-65\% of the production is in the small / micro sector

- Promising technology inflow and Foreign Direct Investment

- World-class institutional support for Design and Product Development, Human Resources Development and R\&D activities

- Presence of support industries like leather chemicals and finishing auxiliaries

- Presence in major markets-Long European experience and strategic location in Asian landmass.

Apart from a significant foreign exchange earner, leather industry has tremendous potential for employment generation. Direct and indirect employment of the industry is around 2 million. The skilled and semi-skilled workers constitute nearly $50 \%$ of the total work force.

\subsection{APPLICATION OF STATISTICAL TOOLS}

\section{Export of leather Products (garments)}

Table 1.1

Export of leather Products (garments)

\begin{tabular}{|c|r|r|}
\hline Year & $\begin{array}{c}\text { Value } \\
\text { (in10 million) }\end{array}$ & $\begin{array}{c}\text { Growth rate } \\
\text { (in \%) }\end{array}$ \\
\hline $2010-2011$ & 333.30 & Base year \\
\hline $2011-2012$ & 309.91 & -7.01 \\
\hline $2012-2013$ & 345.34 & 11.43 \\
\hline $2013-2014$ & 372.87 & 7.97 \\
\hline $2014-2015$ & 387.78 & 3.99 \\
\hline \multicolumn{2}{|c|}{ Compound growth rate $=0.89$} \\
\hline
\end{tabular}

Source: leather products export

It is found from the above table that the Export of leather products regarding garments is presented and also calculated the growth percentage of leather product (garments). The growth percentage is calculated with previous year as base year and values are respectively, in year 2011 is $-7.01 \%$, year 2012 is $11.43 \%$, year 2013 is $7.97 \%$ and year 2014 is $3.99 \%$. The highest growth percentage during the study period is $11.43 \%$.

It is concluded that the year 2012 has high Export of leather products of $11.43 \%$ in garments during the study period. 


\section{Chart 1 Export of Leather garments}

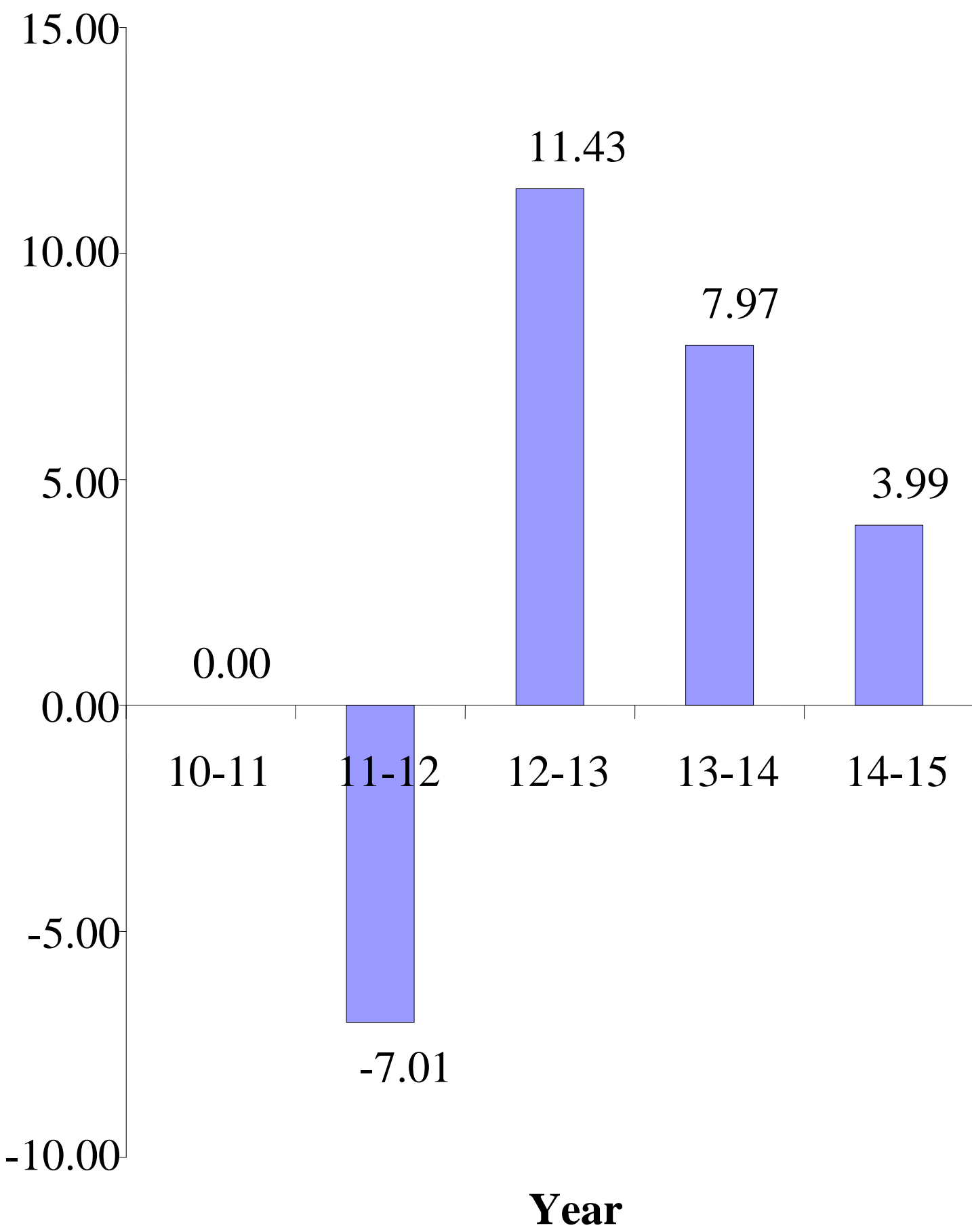




\section{Export of leather goods and accessories}

Table 1.2

Export of leather goods and accessories

\begin{tabular}{|c|r|r|}
\hline Year & $\begin{array}{c}\text { Value } \\
\text { (in10 million) }\end{array}$ & $\begin{array}{c}\text { Growth rate } \\
\text { (in \%) }\end{array}$ \\
\hline $2010-2011$ & 660.17 & Base year \\
\hline $2011-2012$ & 706.28 & 6.98 \\
\hline $2012-2013$ & 800.46 & 13.33 \\
\hline $2013-2014$ & 798.69 & -0.22 \\
\hline $2014-2015$ & 870.06 & 8.93 \\
\hline \multicolumn{2}{|c|}{ Compound growth rate $=0.81$} \\
\hline
\end{tabular}

Source: leather export statistics

It is obtained from the above table that the Export of leather products regarding goods and accessories is presented and also calculated the growth percentage of leather product (goods and accessories). The growth percentage is calculated with pervious year as base year and values are respectively, in year 2011 is $6.98 \%$, year 2012 is $13.33 \%$, year 2013 is $-0.22 \%$ and year 2014 is $8.93 \%$. The highest growth percentage during the study period is $13.33 \%$. The study period have negative growth of $-0.22 \%$ in the year 2013

It is concluded that the year 2012 has high Export of leather products of $13.33 \%$ in goods and accessories during the study period. 


\section{TREND PROJECTIONS}

Table 1.3 Trend to Export of Leather to Germany

\begin{tabular}{|c|r|r|r|r|c|}
\hline Year & $(\mathbf{Y})$ value in crore & \multicolumn{1}{|c|}{$\mathbf{X}$} & \multicolumn{1}{|c|}{$\mathbf{x}^{2}$} & \multicolumn{1}{c|}{$\mathbf{x y}$} & \multicolumn{1}{c|}{$\mathbf{y c}$} \\
\hline $2010-2011$ & 25.20 & -2 & 4 & -50.4 & 15.69 \\
\hline $2011-2012$ & 27.33 & -1 & 1 & -27.33 & 22.08 \\
\hline $2012-2013$ & 28.54 & 0 & 0 & 0 & 28.48 \\
\hline $2013-2014$ & 34.60 & 1 & 1 & 34.6 & 34.87 \\
\hline $2014-2015$ & 26.77 & 2 & 4 & 53.54 & 41.27 \\
\hline
\end{tabular}

Source: export statistics of leather

Trend projection to next five years

\begin{tabular}{|c|r|}
\hline \multicolumn{1}{|c|}{ Year } & $\begin{array}{c}\text { Value } \\
\text { (in10 million) }\end{array}$ \\
\hline $2015-2016$ & 47.66 \\
\hline $2016-2017$ & 54.06 \\
\hline $2017-2018$ & 60.45 \\
\hline $2018-2019$ & 66.85 \\
\hline $2019-2020$ & 73.24 \\
\hline
\end{tabular}

It is clear from the above table that trend analysis is calculated for the leather export to Germany for the next five years from the current study period. According to the trend value, leather export to Germany has expected to grow from $47.66 \%$ to $73.24 \%$ and also noticed that there is a positive growth trend for the next five years. to $73.24 \%$.

It is concluded that leather export to Germany has expected to grow from $47.66 \%$

\section{Findings}

Growth Percentage Analysis

- The year 2012 has high Export of leather products of $11.43 \%$ in garments during the study period. Due to higher productivity and reducing production costs

- The year 2011 has high Export of leather products of $13.78 \%$ in finished leather during the study period. Due to significant growth during this year.

- The year 2012 has high Export of leather products of $13.33 \%$ in goods and accessories during the study period. Due to higher production causes in reduction in growth. 
- The year 2012 has high Export of leather products of $28.96 \%$ in saddler \& harness during the study period. The products are medium in growth due to needs.

- The year 2013 has high Export of leather products of $21.33 \%$ to Germany during the study period. Due to the export orders have come down.

- The year 2013 has high Export of leather products of $16.54 \%$ to Italy during the study period. Due to overseas buyers have gradually started placing orders.

- The year 2012 has high Export of leather products of $28.93 \%$ to France during the study period. Due to some relief to the export oriented sectors.

- The year 2013 has high Export of leather products of $16.57 \%$ to Hong Kong during the study period. Due to some relief to the export oriented sectors.

- The year 2012 has high Export of leather products of $18.17 \%$ to Spain during the study period. Due to overseas buyers have gradually started placing orders.

\section{Trend Projection}

- Leather export to Germany has expected to grow from $47.66 \%$ to $73.24 \%$.

- Leather export to Italy has expected to grow from $127.22 \%$ to $135.23 \%$.

- Leather export to France has expected to grow from $8.70 \%$ to $10.45 \%$.

- Leather export to Hong Kong has expected to grow from $260.30 \%$ to $311.66 \%$.

- Leather export to Spain has expected to grow from $27.58 \%$ to $32.06 \%$.

- Leather export of foot wear has expected to grow from $3797.90 \%$ to $6249 \%$.

- Leather export of garment has expected to grow from $401.41 \%$ to $470.17 \%$.

- Export of finished leather has expected to grow from $905.25 \%$ to $1098.90 \%$

\subsection{CONCLUSION}

The above study was carried out with the prime objective of analyzing the export performance of leather in India. The levels of analysis reveals economic fundamentals are important in accelerating the exports. The study suggests many ideas to import the leather manufactures and export of leather to various countries through various products of leather. The study also found that there was beer tremendous increase in leather exports to many countries while it is low only in few countries. Therefore the government should take various steps to improve the exports of leather to greater levels and provide more policies to promote exports and the countries should take active part to increase export performance.

\section{Reference}

1 Duraivalan.C.K, Growth of leather industry, vol.127, Dec 1973, p-20

2. CLE Reports on innovations in leathers and fashion materials, leather news India vol.12, No.4, April 2011.

3. Kumerasan, "Export performance of leather and related goods", facts for you vol.29,No.12, Sep 2009, p-60.

4. Barat, "Development of leather industry in the Third World, Vo. 23, No.2, Nov. 1970.

5. Global export import market intelligence.

6. www.google.com 